Trivent Publishing

(C) The Authors, 2018

Available online at http:/ / trivent-publishing.eu/

TRIVENT

Series: Applied Ethics: From Bioethics to Environmental Ethics

\title{
Genes, CRISPR/Cas 9, and Posthumans
}

\author{
Stefan Lorenz Sorgner \\ John Cabot University, Italy
}

Abstract: The following three re-evaluations lead to a radical paradigm shift which has occurred at least since Darwin's times:

1. A move from a dualist anthropology towards a non-dualist one

2. A radical increase of anthropotechniques with the power of enhancing human capacities so that the likelibood of the posthuman coming about can be increased

3. The posthuman can come about by means of digital technologies or with the belp of biotechnologies whereby the field of genetics, on which I focus here, is particularly relevant

These three basic insights lead to a massive number of intellectual, social, political, ethical, and economic challenges. In the following reflections, I will present a selection of emerging bioethical issues concerning gene technologies, in particular CRISPR/Cas 9, and how they can be addressed in an appropriate manner within a wider cultural context.

Keywords: Genes; dignity; posthuman; emerging technologies; personhood; instrumentalization.

This is an Open Access article distributed in accordance with the Creative Commons Attribution Non Commercial (CC-BY-NC-ND 4.0) license, which permits others to copy or share the article, provided original work is properly cited and that this is not done for commercial purposes. Users may not remix, transform, or build upon the material and may not distribute the modified material (bttp:/ / creativecommons.org/licenses/by-nc/4.0/) 


\title{
Genes, CRISPR/Cas 9, and Posthumans
}

\author{
Stefan Lorenz Sorgner
}

We live in an age where paradigm shifts occur in numerous fields of the life world. Most recently, a news report went through the media that a biobag was invented in which a little sheep was successfully grown. This invention has potentially enormous implications, in particular, if we combine this technology with further advances in the field of gene technologies. Discussing the exponential growth of emerging technologies and correlated changes does not imply a derogatory judgement concerning these developments. On the contrary, artificial wombs might be the key technology concerning gender equality at the workplace. If combined with further gene technologies, it has the potential to actively imply radical consequences concerning the future of humanity, an option we have never had before. Nevertheless, these promises as well as the challenges related to enhancing evolution can be expected soon, and the coming about of the posthuman perspective is particularly relevant in this context. It is related to the following insights:

4. A move from a dualist anthropology towards a non-dualist one

5. A radical increase of anthropotechniques with the power of enhancing human capacities so that the likelihood of the posthuman coming about can be increased

6. The posthuman can come about by means of digital technologies or with the help of biotechnologies whereby the field of genetics, on which I focus here, is particularly relevant

These three basic insights lead to a massive number of intellectual, social, political, ethical, and economic challenges [1]. In the following reflections,I will present a selection of emerging bioethical issues concerning gene technologies, in particular CRISPR/Cas 9, and how they can be addressed in an appropriate manner within a wider cultural context. Taking the stance that 
these developments should not occur and demanding that these technologies should not get developed is not a realistic option. If these technologies are not developed in one country, they will be realized in another one. If scientists and engineers do not receive permission to conduct research in any country, they will create permanent dwellings at sea outside the realms of national governments, i.e. by means of sea-steading.

\section{Non-dualist understanding of human beings}

Zarathustra might have been the first to create a rigid distinction between good and evil. This categorical distinction in most philosophies goes along with categorical dualist ontological distinction, and in particular with the understanding that all human beings consist of an immaterial soul, consciousness or mind, and a material body. This insight has been dominant in Western philosophies since at least Plato, who clearly separated the realm of forms which can be accessed by means of thinking from the sensual realm in which we live. This basic insight was accepted by most Western philosophers. Each one adapted it to their own individual understanding. According to both Plato and the Stoics, all human beings have a rational soul. However, for the Stoics, this is the reason why all human beings should be considered moral equals, too, which was not the case according to Plato's thinking. Descartes agrees with the stoic insight of human beings possessing a rational soul. However, he holds that only human beings have any type of soul. Animals consist of matter only. The Stoics and Plato, on the other hand, claim that there are further types of souls which animals and plants possess. In many respects, Kant agrees with Descartes' understanding of animals and human beings, but Kant uses these insights for developing a complex ethics on this basis, an ethics which is still widely taken for granted today [2]. Even the German foundational law has its intellectual basis on the concept of human dignity, a concept which can only be fully understood when having a grasp of Kant's ethics [3]. Only human beings have dignity. Animals, plants, and stones should be treated like things. They all fall under the object law. It is the distinction between subjects and objects or, in moral terms, between things and persons - an idea which has its intellectual root in the dualist anthropological tradition which has been dominant in Western countries since at least Plato. It also has significant practical implications raging from the prohibition of peep shows to the prohibition to shooting down hijacked planes which fly into nuclear power stations to the moral status of animals and how animals can be treated within experiments.

However, this anthropology has become less and less plausible from the end of the $19^{\text {th }}$ century onwards due to insights put forward by Darwin, Nietzsche, and Freud. We no longer regard ourselves as being categorically 
separate from this world concerning our ontological status - we no longer hold that we have a material body and an immaterial soul. It is a more modest way of thinking, as it moves away from the traditional human hybris of possessing a categorically special status in the world. This does not mean that we do not possess special qualities. Learning a human language might merely be possible for human beings. However, animals also have such special qualities. Vampire bats manage to detect blood by means of infrared sensors. It is their special capacity. Animals, too, can have special abilities. Moving away from the traditional anthropology implies that it is no longer plausible that only human beings participate in the immaterial realm, and are consequently attributed personhood, whereas all other beings are seen as things or objects. However, this is still the qualification which is legally valid in Germany and in many other countries.

I am not claiming that we should replace a dualist anthropology with a non-dualist one concerning the legal realm, because in this way we would replace one fundamentalist view with another one, whereby neither one is shared by all citizens. However, this insight leads to my suggestion that such strong anthropologies and ontological positions should not be part of liberal democracies, because they come in conflict with the plurality of world views which we can find in all liberal democracies today. This shift is fundamentally relevant for all the other developments I will be presenting. Seeing ourselves as merely gradually separate from all other animals implies that, in the same way as they have come about on the basis of evolutionary processes, this also applies to us. In the same way as all other species of animals can die out, this insight also applies to us, if we do not adapt appropriately. If we do not adapt to the permanently-changing environment, we will die out. However, if we do adapt, we will develop further, via transhumans, i.e. further developed humans, and, if we are lucky, towards the posthuman, i.e. becoming members of a new species. This is one reason why technologies are of immense relevance, but it is by far not the only reason for using technologies [4].

\section{Personhood for animals, robots, and artificial intelligence (AI)}

One of the implications of the revised understanding of human beings, as described above, is the relevance of moving away from the anthropocentric basis for evaluating the moral status of an entity, as it implies speciesism, which has morally-problematic implications. Peter Singer was right when he explained that attributing personhood solely and exclusively to human beings implies speciesism. Moral recognition should depend on morally-relevant capacities and not solely on someone's belonging to a specific species. I am not embracing Singer's counter suggestion, which focusses on the relevance of self-consciousness and sentience, as these imply an intense capacity of 
experiencing pain, and this ability should be the basis of a moral status [5] [6]. Still, it is a strong suggestion. Self-consciousness is a fascinating trait. Whoever possesses it seems to be more prone to suffering than those who do not have it [7] (Morton 2000). Furthermore, the capacity to suffer seems to be relevant for evaluating the moral status of an entity. The mirror test is widely taken for granted as a reliable way for testing whether an organism has selfconsciousness. "Currently, 9 non-human animal species pass the mirror test. Not all individuals of each species pass, but many do" [8]. Still, one could wonder whether the test is biased on the eyes. Maybe, self-consciousness in some organisms is more closely related to hearing or smelling, e.g. dogs who do not pass the mirror test. What alternative tests could be applied? Furthermore, there seems to be a close connection between the mirror test, self-consciousness, and our current selfie culture. Speaking of this, can Dürer's self-portrait be analysed as a selfie?

Yet, Singer's suggestion has implications which are not regarded as plausible by most enlightened people. By means of his theoretical stance, it is possible to morally justify the killing of a new-born human being which seems counter-intuitive. However, our widely shared emotional reaction towards this consequence might just be our lack of emotional morality, as we have been overtly and strongly shaped by the traditional Judeo-Christian tradition. If this is the case, it might just be a matter of time until we will have adapted our emotional morality to our theoretical morality.

In any case, Singer's suggestion represents a move into the right direction. An interplay between three pillars (widely shared moral intuitions, the latest scientific insights, and a recognition of the relevance of negative freedom) should provide us with a basis for evaluating the moral status of any type of entity [9]. In addition, cultural embeddedness needs to be taken into the consideration. My approach is narrative and hermeneutic, stressing the relevance of discourse plus the recognition of the relevance of the aforementioned three pillars. This position takes into consideration that social situations and moral evaluations are permanently subject to change and that such changes are relevant for the legal evaluation of entities. In addition, it is a procedural solution which does not aim for a perfect state and solution because it recognizes the relevance of movement and change in the field of morality.

This position can also integrate new developments, like the option of creating hybrids. The UK has permitted to create chimeras consisting of animals and humans, if they are destroyed within two weeks after their realization. However, why should they have to be destroyed? We lack a basis for evaluating the moral status of these hybrid entities. They do not go against human dignity, as these entities are no human beings. The potential of these beings can be enormous. Dutch scientists have already managed to genetically 
engineer zebra fish so that they can use photosynthesis for nourishment purposes. The fish turn slightly green as part of this process, but it works. Genetically zebra fish are not so different from human beings. Maybe, the little green human beings from Mars are actually our future [2, p. 169-171].

Furthermore, it must be considered that we are already hybrids. Our skin and in intestines contain an enormous amount of bacteria and other microbes. A human body consists of more non-human cells than of human cells, and we could not survive without these cells. This insight can be particularly relevant for the future of xenotransplantation. Martine Rothblatt, a transgender transhumanist, owns a pig farm for genetically engineering pigs so that their lungs can be transplanted into human beings without the risk of them being rejected. It seems like a promising attempt. She is particularly interested in this procedure as her daughter is suffering from a life-threatening lung disease.

However, moving away from attributing a categorically-special status solely to human beings can also imply that, given the appropriate developments, we may have to attribute personhood to computers or AI. Researchers are already trying to see whether consciousness is a phenomenon based on the complexity of neuronal structures by attempting to imitate the complexity of a cat's brain using one computer per neuron. However, consciousness may not even be needed gaining a special moral status. How should we treat a computer with super-intelligence?

Katherine Hayles provides reasons for claiming that there can be something like non-conscious cognition, and if this is the case, it might be plausible to expand the circle of entities which should be morally considered [10]. This thought is based on the following reflections. If we are humiliated, we do not necessarily experience the feeling of suffering. Being humiliated might simply be connected to the cognitive realisation that one is not valued by someone else, and we do not appreciate not being valued. Humiliation could be a problematic relation not only for self-conscious beings, but also for non-conscious, but cognitive entities, i.e. androids like Data from Star Trek. If this is the case then it could make sense to claim that the cognitive capacity to grasp how one is valued is another relevant basis for evaluating the moral status of an entity, which could be a basis for attributing a moral status to certain robots. In any case, it needs to be noted that the move away from an anthropocentric world-view and the corresponding new understanding of a moral status is central for future bioethical challenges, and it is of particular relevance when we deal with moral issues concerning gene technologies. 


\section{The dissolution of the moral prohibition to treat a person as merely a thing, as both personhood as well as thinghood no longer exist in their traditional form}

The person-thing distinction, which goes back to Kantian philosophy, has numerous general moral implications [3]. One of them is the moral prohibition to treat a person as merely a thing. In Germany, this principle implies that peep shows are legally forbidden and that it is forbidden to shoot down a hijacked plane which seems to be directed towards a nuclear power station as long as there is at least one innocent being on board. In both cases, a person would be treated as merely an object. In the case of the hijacked plane, the innocent pilot, for instance, would die anyway but millions of lives could be saved, if the plane was shot down. However, this would imply that the government treated the innocent pilot as an object in order to save the lives of a million people. Such utilitarian calculations go against the ethics of human dignity and the traditional understanding of personhood which leads to the above-mentioned moral prohibition. However, if the traditional personthinghood distinction is no longer plausible, the moral prohibition is no longer applicable either. Hence, we need to find a new basis for moral principles which is not an easy task, because the traditional understandings of personhood and thinghood are part of many legal constitutions and have highly significant implications for our life world. It is a task with which we need to deal with in order to morally shape the future. Do we treat a fertilized egg solely as a means, when we select it after in vitro fertilization and preimplantation genetic diagnosis? Do parents treat their offspring just like an object, if they decided to genetically modify them? [11].

\section{The plurality of the good (cognitive capacities, morality, and new family concepts)}

Once we take this new anthropology seriously and we understand that all aspects of our existence participate in evolutionary processes, the following question needs to be asked anew: What can be said about living a good life? Some transhumanists suggest strong concepts of the good, like the validity of the Renaissance ideal. It might not be possible for all of us, but we do desire to be intelligent, beautiful, strong, healthy, and have all the other strengths which are associated with the Renaissance ideal of human perfection. Other liberal or naturalist bioethicists, such as Julian Savulescu [12] [13], are more sympathetic with a common sense approach. You live a good life, if you possess the following qualities:

1. Not being disabled whereby disability is seen as context-dependent quality; 
Stefan Lorenz Sorgner

Genes, CRISPR/Cas 9, and Posthumans

2. No disposition for mental illnesses;

3. Having good health;

4. Good capacities for communication, memory, and empathy;

5. High intelligence.

I do not regard these suggestions as plausible, as universal validity implies their application to all human beings at all times in all parts of the world. I, on the other hand, regard a radically-pluralist account of the good life as most plausible [14]. Only by listening to and acting in accord with someone's psychophysiological demands does a person become authentic. Consequently, the following acts can be understood as based on authentic wishes (this does not need to be the case in all instances, but can be): (1) Person A wishing to die; (2) Person B desiring to have her healthy leg removed; (3) Person C wishing to eat parts of himself; (4) Person D not wanting to be cured from her manic depression; (5) Person E regarding his deafness as an advantage and not as a disablement. The list of potential examples could easily be continued. If the Renaissance genius account or the commonsense account of the good were universally valid, these wishes could not be accepted as authentic, but would be seen as expressions of an ill mind.

I do not think that this has to be the case. By claiming that these wishes represent insane states of the mind, these persons are treated paternalistically and violently: their wishes are not recognized as their own, and others claim that they know better than oneself what is in one's own interest. I regard such a way of treating people as highly problematic because the otherness of someone else's wishes does not get appropriately appreciated. On the one hand, there are culturally-dominant paradigms of leading a good life; on the other hand, there are the needs of one's own psychophysiology that do not necessarily correspond to these general demands. A pregnant woman who wishes to have sex with men other than the father of her child, a student who enjoys sexual intercourse with several people at the same time, and a young girl who is longing for erotic encounters with a woman thirty years her senior represent three examples in question. All of these desires do not get approval from culturally-dominant paradigms of a good life; but there are people with such desires, and it is aggressive, violent, and paternalistic to approach them by claiming that they do not understand themselves in an appropriate manner because these types of acts do not correspond to the concept of good life, which the culture in question regards as valid. Initially, it was difficult for me, too, to imagine that it can be the case that a deaf person is not disabled but merely different. However, by recognizing the wide range of preferences, choices, tastes, and cultures in all parts of the world at various times, I came to realize how important it is to recognize that a different human being might regard different capacities as important and different shapes as attractive. 
This approach has implications for dealing with the concept of family [2, $\mathrm{p}$. 166-168]. A good example is the option of creating children with three biological parents. The UK is the first country worldwide which approved the necessary technologies for having such children. It is a very simple technology by means of which the nucleus of one female egg is removed and replaced by the nucleus of a different egg. In this way, the risk that a mitochondrial genetic disease is transferred from a mother to her child is excluded - the mitochondria are not in the nucleus but in the cytoplasm which surrounds it. Afterwards, the new egg is fertilized so that the child with three biological parents can come into existence. The UK has approved this procedure solely for mothers with this mitochondrial disease. However, it could also be a useful tool for a lesbian couple or two women and a man having a biologically related child. If three adults have a biologically related child this way, why should not they be allowed to marry, if this is their desire? Adults and a biological child are the basic constituent for a legal family in most cultures. However, this example reveals the enormous social implications, if posthuman perspectives are considered.

\section{Self-overcoming and the good life (the relevance of a prolonged health span)}

It is also possible to make claims valid for a great percentage of people. In this respect, a good health and a prolonged health span are widely shared qualities. Furthermore, it can be said that permanent self-overcoming is often identified with an increase of fulfilment. The following example helps in understanding this issue. Life as a child in a protected family is easier than life as a student. However, if you asked a student whether they would want to be a child again, most students would decline that offer, because they value the cognitive capacities, intelligence, and knowledge they possess. These goods are not solely positional goods, but they are also intrinsic goods which people do not wish to give up once they possess them. Similarly, as children cannot imagine what it would be like as students, students cannot imagine what it would be like as posthumans. Following this analogy, once we are posthuman, we would not want to be students anymore [2, p. 158-159].

\section{Autonomous self-overcoming and heteronomous self-overcoming}

It must be stressed that the technologies discussed should not be used to legally force people to use them in a certain way. We agree that it is a wonderful achievement to live in a liberal and pluralist society. Consequently, there are two options for using emergent technologies: by means of autonomous self-overcoming and by means of heteronomous self-overcoming whereby the second option does not allow political and religious leaders of 
other institutions to make a decision concerning who gets altered, but it refers to the very special parent-child relationship, in which such decisions are necessary and useful.

\section{Gene technologies}

Given the potential of CRISPR/Cas9, the so-called gene scissors which enables a precise, reliable and cheap way of modifying genes, I regard the future of human progress as closely related to a continued carbonate-based existence, which is particularly related to genetic research: gene creation by means of synthetic biology, gene modification, gene selection and analysis, and big gene data are four highly relevant fields in this context.

Synthetic biology is the attempt to create biologically-useful systems. Craig Venter's research is particularly notable in this field. He created a partiallysynthetic species for which he is trying to get a patent which raises the ethical question concerning gene patents. He also claims to be the first to have created synthetic life. However, the Presidential Commission for the Study of Bioethical Issues holds that he has not created life. A closely-related field is that of biohacking which refers to a movement of do-it-yourself-at-homebiologists who conduct gene sequencing by means of easily-accessible methods and technologies. Both fields are thriving and it is worth getting further information on them.

A separate but related and much more intensely-discussed field is that of genetic modifications. For the past 15 years, it has been the subject of intense ethical discussions, and most leading ethicists in the world have taken a stance within this debate. The most noteworthy from a bioconservative perspective is the analysis and position Jürgen Habermas [15]. He regards genetic modifications for therapeutic goals as morally-legitimate, because, in this case, an all-purpose goal is promoted. The use of genetic modifications for enhancement purposes, on the other hand, is morally false, because, according to him, in this case persons get treated merely like objects. In addition, he presented reasons for rejecting a powerful pro-enhancement argument which analyses genetic enhancements and traditional education as structurallyanalogous procedures. In both cases, parents make decisions for their offspring. Habermas claims, however, that genetic modifications are always irreversible and educational modifications are always reversible. Contemporary gene research and in particular epigenetics show that both premises are highly dubitable, if not clearly false. Consequently, there are strong reasons to claim that genetic modifications and traditional education are structurally-analogous processes. As structurally-analogous processes should also be treated as morally analogous, it may be concluded that both genetic and educational modifications can be morally-blameable- as well as praiseworthy - therefore, 
genetic enhancements do not have to be morally objectionable. This was a very short summary of an argument I have developed in great complexity and was published in 2015 in the Journal of Evolution and Technology [16]. It should also be noted that human genetic modifications cannot be yet reliably done on a day to day basis. However, scientific research and particularly the invention of CRISPR/Cas9 show that gene modifications can be undertaken precisely, reliably, and cheaply and that they can be successful without having side effects. Thus it is merely a matter of further research to turn this technology into a reliable one. I regard this issue as the most powerful technological invention of this decade. Furthermore, this issue will keep bioethicists particularly occupied in the forthcoming years.

Another separate issue is that of gene selection. It must be noted here that this is already a reliable technology. It presupposes in vitro fertilization which means that an egg gets fertilized by means of a sperm within a petri dish. After several divisions of the fertilized egg, it is possible to take one fertilized egg and analyse it genetically. Thereby, a great variety of information can be found, such as character traits, health information, and responsiveness to certain pharmacies. Then, it can be decided whether the fertilized egg from which the cell was taken should be implanted in the womb or not. Several issues are discussed in this context: What is the moral status of the fertilized egg? What is the status of the analysed cell which gets destroyed? Is it moral to select a fertilized egg after IVF and PGD (preimplantation genetic diagnosis)? Habermas responded in the same way as in the prior case: it is immoral, because a person is treated merely as an object, thus it is an immoral procedure. However, he does not recognize that fertilized eggs do not have to be identified with a person. For many people, a fertilized egg which consists of eight cells is merely a lump of cells and should not be identified with a fully developed human being. This position receives further support from the fact that 7 out of 10 fertilized eggs which come about by means of traditional procreation are never realized, but are eliminated with a slightly stronger monthly period. In addition, it needs to be understood that selecting a fertilized egg and selecting a partner for procreative purposes are structurally analogous procedures [17]. Just as a government should not interfere in one's selection of a procreative partner, a government should not interfere when we wish to select (or not) a fertilized egg after IVF and PGD.

Furthermore, gene analysis will be even more relevant than gene selection. Progress in this field is particularly noteworthy given the parallel creation of big gene data [18]. Such an analysis can tell you how likely it is for one to get a certain disease, it can reveal something about one's reaction to certain pharmacological products, and it can describe some of one's strengths and weaknesses. It is in our own interest to having such an analysis. On the basis of such an analysis one can change their life so that life goals are promoted by 
considering one's genetic dispositions. The costs of such an analysis are continuously getting lower. However, in this case, the issue of bioprivacy (or, more precisely, that of genetic privacy) arises - or rather the dissolvent of the concept of one's genetic privacy. The problem is already explicit. Let us consider the German legal system. It is already a legal obligation to give away the information of an already-made gene analysis, if you wish to make an insurance with a high financial risk for the insurance company. Consequently, anyone considering the option of having such an insurance, cannot realistically risk to have their genes analysed, although it could be in their personal interest to undergo such a gene analysis.

However, it is not only the person in cause who is interested in one's genetic information. Potential future employers, insurance companies, and the government could also be highly interested in this information. Once the data is available, it is digitally and hence publicly available, because we have reasons for holding that anything digitally available online is no longer private information, because it is already part of the internet panopticon. Still, the challenge goes even further, because one shares many central aspects of their genetic data with many of their family members. Even if one is not willing to give away this information, it is possible to get hold of the same data by asking their brother with whom they might not have spoken for years. Furthermore, one also needs to consider that by giving away genetic data, because of wanting to find information on one's family tree, one is giving away information about one's sister, too, although she did not permit this information to be out there. The question of genetic privacy represents significant further stepping stone concerning the future of technological developments.

In 2015, Kuwait has already made it legally obligatory for all citizens and residents to deliver tissue samples. If they do not or if they deliver false samples, they would face numerous years in prison. The official justification for this decision is fighting crime and terrorism. If successful in Kuwait, this legislation has the potential to be employed in more countries over the world. The technology is available, and many people are using it, because it provides us with important and fascinating information. 23 andme ${ }^{1}$ has more than a million customers worldwide. Genetic information could be extremely useful for the future. However, gene analysis also has the potential of radically change the way societies are structured in the near future. Hence, genetic privacy is an issue which desperately needs to be discussed further by bioethicists, in particular the question on who should own the information of a gene analysis: Should it be me, because the information belongs to my genes? Should it

\footnotetext{
123 andme is the first company to offer autosomal DNA testing for ancestry. See more: https://www.23andme.com/en-int/
} 
belong to the analysis company, because they are mixing their labour with the genetic material, and mixing one's labour with something is the basis for acquiring property? Or maybe, the information should belong to all biological members of a family, as they are sharing a great amount of the information, and it could have negative implications for all of them?

The realms of gene technology and computer technologies merge at this point. We have big gene data which encloses important information about one's physiology and big IT data by means of which important psychological information is revealed. Furthermore, cartographies of all our movements are being digitally stored, by means of public surveillance and facial recognition software, telephone traces, and GPS data of in-car navigation systems. All three fields of data are digitally stored and processed on the internet, which again turns all the information into publicly available data. All central aspects of one's personality are revealed within the internet panopticon where citizens of all technologically-advanced countries are imprisoned. It is an unpleasant situation, which alters one's behaviour, once you are fully aware of your situation. However, a solution for this situation is far from clear.

\section{Conclusion}

This chapter provides a summary of the most important current and future bioethical challenges we are facing. Most of them belong to the field of gene ethics, as by means of these technologies we have the potential to radically alter the set-up of our societies and even of enhancing evolution - therefore, the likelihood of evolving into posthuman increases. This shift is not independent of a further ontological paradigm shift which has been occurring since the $19^{\text {th }}$ century, and it is related to a revised self-conceptualization. We no longer regard ourselves as categorically dualistic entities which consist of a material body and an immaterial soul, but an increasing amount of human beings conceptualize themselves as non-dualist relational entities who are in a permanent process of self-overcoming. Consequently, we have to seriously consider that it would be naive to assume that homo sapiens sapiens represent the final step of the evolutionary process. We need to realize that we will either die out or evolve further, as stagnation would necessarily lead to human extinction - if not now, then at least in 5 billion years when the sun will explode and destroy our entire solar system. This wider picture plays a central role in refocusing our debates in the field of bioethics. 


\section{References}

[1] R. Ranisch, S. L. Sorgner. "Introducing Post- and Transhumanism." 7-29. In Ranisch, R./ Sorgner, S.L. Post- and Transhumanism. An Introduction, ed. R. Ranisch, S. L. Sorgner. Frankfurt a. M.: Peter Lang, 2014.

[2] S. L. Sorgner. Transhumanismus: 'Die gefährlichste Idee der Welt'?? Freiburg i. Br.: Herder, 2016.

[3] S. L. Sorgner. Menschenwürde nach Nietzsche: Die Geschichte eines Begriffs. Darmstadt: WBG, 2010.

[4] S. L. Sorgner. "Human Dignity 2.0. Beyond a Rigid Version of Anthropocentrism." Trans-Humanities 6(1) (2013): 135-159.

[5] P. Singer. Animal Liberation. New York: Harper, 2002.

[6] P. Singer. Practical Ethics. Cambridge: Cambridge University Press, 2011.

[7] D. B. Morton. "Self-consciousness and animal suffering." In Biologist (London)47(2) (2000):77-80.

[8] http:/ /www.animalcognition.org/2015/04/15/list-of-animals-that-havepassed-the-mirror-test/, accessed: 11.02.2018.

[9] S.L. Sorgner. "Metahumanist Politics and Three Types of Freedom." In European Journal of Science and Theology 11(1) (2015): 119-129.

[10] Hayles N. Katherine. Unthought: The Power of the Cognitive Nonconscious. Chicago: University of Chicago Press, 2017.

[11] S. L. Sorgner. "Kant, Nietzsche and the Moral Prohibition of Treating a Person Solely as a Means." In The Agonist 4(1-2) (2013): 1-6.

[12] J. Savulescu. "Procreative Beneficence: Why We Should Select the Best Children." In Bioetbics 15 (5-6) (2001): 413-26.

[13] J. Savulescu, G. Kahane. "The Moral Obligation to Create Children with the Best Chance of the Best Life." In Bioethics 23(5) (2009): 274-90.

[14] S. L. Sorgner. "The Renaissance Ideal, the Common-Sense-Ideal, and the Radical Plurality of Goodnesses The Transhumanist Types of (Post)Human Perfection." 141-157. In Perfecting Human Futures: Transhuman Visions and Technological Imaginations, ed. J. B. Hurlbut, H. Tirosh-Samuelson. Wiesbaden: Springer, 2016.

[15] J. Habermas. Die Zukunft der menschlichen Natur. Auf dem Weg zu einer liberalen Eugenike? Frankfurt am Main: Suhrkamp, 2001.

[16] S. L. Sorgner. "The Future of Education: Genetic Enhancement and Metahumanities." In Journal of Evolution and Technology 25(1) (2015): 31-48.

[17] S. L. Sorgner. "Is there a "Moral Obligation to Create Children with the Best Chance of the Best Life'?" In Humana Mente: Journal of Philosophical Studies 26 (2014): 199-212.

[18] S. L. Sorgner. "Genetic Privacy, Big Gene Data, and the Internet Panopticon." In Journal of Posthuman Studies: Philosophy, Media, Technology 1 (2017): 87-103. 